Prepared in cooperation with the U.S. Environmental Protection Agency

\title{
Inventory and Statistical Analysis of Sediment Data for Streams in Kentucky, 1950-2008
}

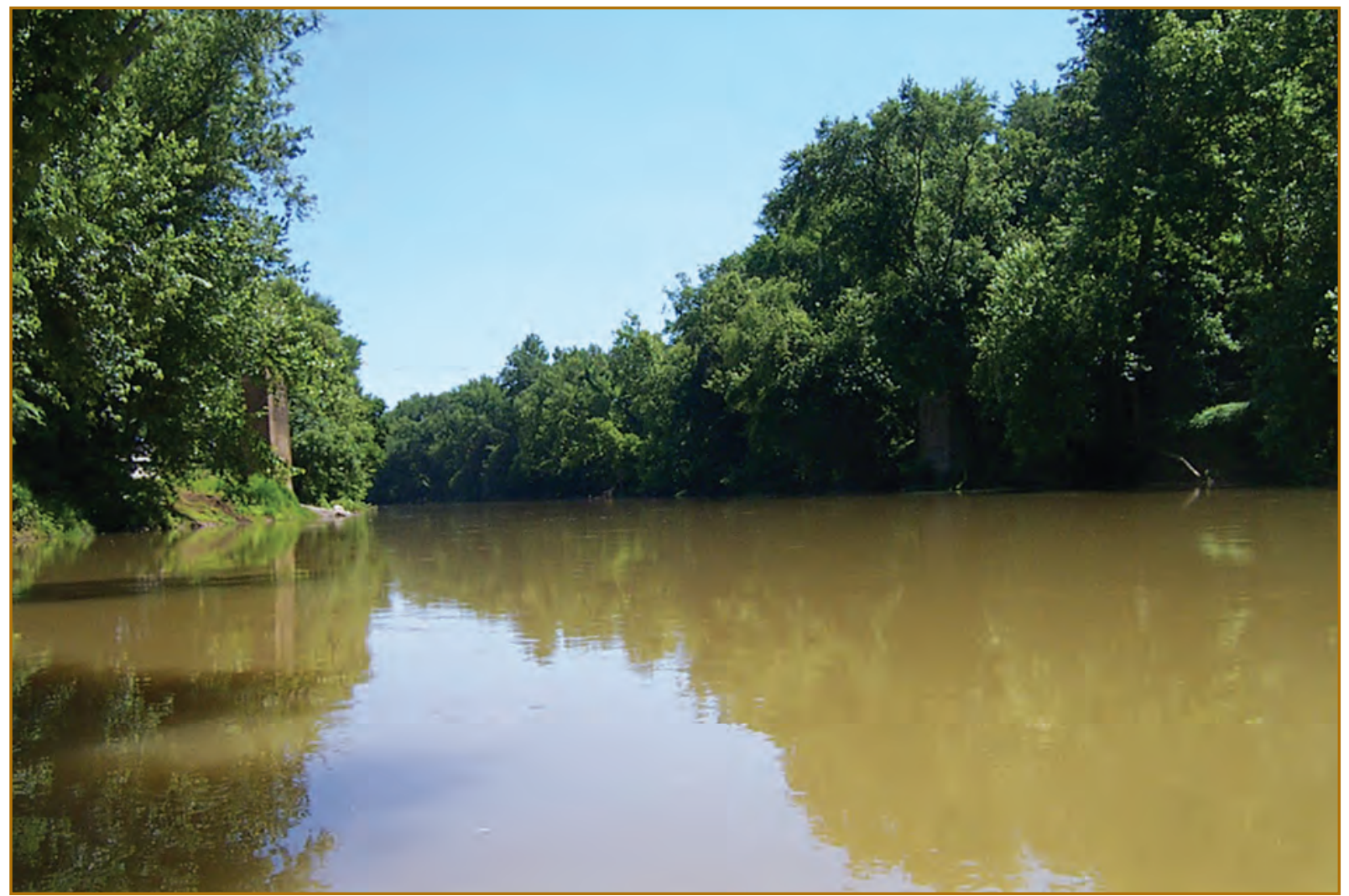

Scientific Investigations Report 2009-5035 
Cover photo. USGS site ID 03308500 , the Green River at Munfordville, Kentucky. 


\section{Inventory and Statistical Analysis of Sediment Data for Streams in Kentucky, 1950-2008}

By Tanja N. Williamson

In cooperation with the U.S. Environmental Protection Agency

Scientific Investigations Report 2009-5035 


\title{
U.S. Department of the Interior \\ KEN SALAZAR, Secretary
}

\author{
U.S. Geological Survey \\ Suzette M. Kimball, Acting Director
}

U.S. Geological Survey, Reston, Virginia: 2009

For more information on the USGS - the Federal source for science about the Earth, its natural and living resources, natural hazards, and the environment, visit http://www.usgs.gov or call 1-888-ASK-USGS

For an overview of USGS information products, including maps, imagery, and publications, visit http://www.usgs.gov/pubprod

To order this and other USGS information products, visit http://store.usgs.gov

Any use of trade, product, or firm names is for descriptive purposes only and does not imply endorsement by the U.S. Government.

Although this report is in the public domain, permission must be secured from the individual copyright owners to reproduce any copyrighted materials contained within this report.

Suggested citation:

Williamson, Tanja N., 2009, Inventory and statistical analysis of sediment data for streams in Kentucky, 1950-2008: U.S. Geological Survey Scientific Investigations Report 2009-5035, 23 p. 


\section{Contents}

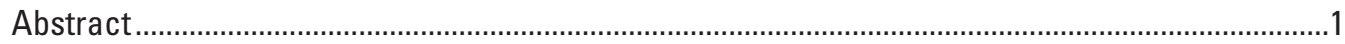

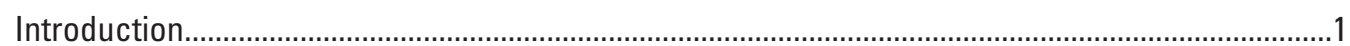

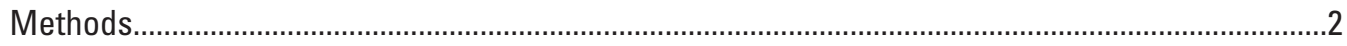

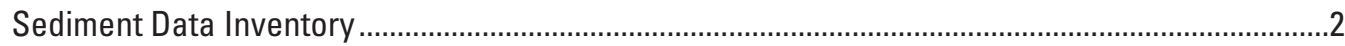

Statistical Analysis of Selected Sediment and Nutrient Parameters ..............................................10

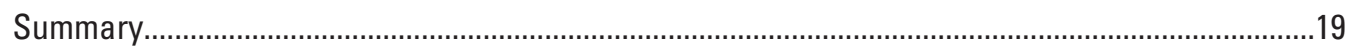

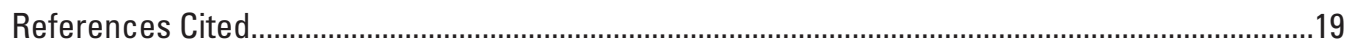

\section{Figures}

1. Map showing the distribution of historical U.S. Geological Survey

sediment-monitoring sites across Kentucky for which there are long-term water-quality records and location of active sediment-monitoring sites at the end of 2007 .

2-6. Graphs showing:

2. Sample-collection dates of suspended-sediment concentration at U.S. Geological Survey sites in Kentucky for which there are long-term water-quality records

3. Sample-collection dates of total suspended solids at U.S. Geological Survey sites in Kentucky

4. Coincident sample-collection dates of suspended-sediment concentration and total suspended solids at U.S. Geological Survey sites in Kentucky

5. Sample-collection dates of turbidity at U.S. Geological Survey sites in Kentucky

6. Coincident sample-collection dates of suspended-sediment concentration and turbidity at U.S. Geological Survey sites in Kentucky

7-11. Boxplots of:

7. Suspended-sediment-concentration data for the 42 sites in Kentucky at which at least one other sediment parameter (total suspended solids or turbidity) was monitored.

8. Total-suspended-solids data for the six sites in Kentucky at which suspended-sediment concentration was coincidentally monitored

9. Turbidity data for the 42 sites in Kentucky at which suspended-sediment concentration was coincidentally monitored

10. Total-nitrogen data for the 42 sites in Kentucky at which suspended-sediment concentration and at least one other sediment parameter were monitored

11. Total-phosphorus data for the 42 sites in Kentucky at which suspended-sediment concentration and at least one other sediment parameter were monitored

12. Scatterplot and Pearson's product-moment correlations of five water-quality parameters for each of the coincident observations discussed in the text 


\section{Tables}

1. Long-term stations where at least one sediment parameter was monitored

2. Statistical summary of selected water-quality parameters for sites where suspended-sediment concentration and at least one other sediment parameter were coincidently monitored.

3. Regression of suspended-sediment concentration on total suspended solids, turbidity, and discharge.

4. Regression of suspended-sediment concentration on total suspended solids for individual sites

5. Regression of suspended-sediment concentration on turbidity and discharge for individual sites.

6. Regression of suspended-sediment concentration on total suspended solids, turbidity, and discharge for individual sites

\section{Conversion Factors}

\begin{tabular}{lll}
\hline \multicolumn{3}{c}{ SI to Inch/Pound } \\
\hline \multicolumn{1}{c}{ Multiply } & \multicolumn{1}{c}{ By } & \multicolumn{1}{c}{ To obtain } \\
\hline milligram $(\mathrm{mg})$ & 35.27 & ounce, avoirdupois (oz) \\
liter $(\mathrm{L})$ & 0.2642 & gallon (gal) \\
\hline
\end{tabular}

Concentrations of chemical constituents in water are given in milligrams per liter ( $\mathrm{mg} / \mathrm{L})$.

\section{Abbreviations}

FNU Formazin nephelometric units

NTU Nephelometric turbidity units

NWIS National Water Information System

p Parameter

SSC Suspended-sediment concentration

TN Total nitrogen

TP Total phosphorus

TSS Total suspended solids

USGS U.S. Geological Survey 


\title{
Inventory and Statistical Analysis of Sediment Data for Streams in Kentucky, 1950-2008
}

\author{
By Tanja N. Williamson
}

\section{Abstract}

Suspended sediment is a constituent of water that is monitored because of concerns about accelerated erosion, nonpoint contamination of water resources, and degradation of aquatic environments. Understanding the availability of monitored sediment data for streams in Kentucky is critical to planning future modeling and monitoring efforts. In order to assess the availability of sediment data for Kentucky, longterm records were obtained from the National Water Information System (NWIS) of the U.S. Geological Survey (USGS). Suspended-sediment concentration (SSC), the parameter traditionally measured and reported by the USGS, was statistically compared to turbidity and total suspended solids (TSS), two parameters that are considered surrogate data. Coincident observations of SSC with either turbidity or TSS were available for 42 sites. In combination with instantaneous streamflow, turbidity and TSS both proved to be significant indicators of SSC when data from all sites were used. Because of the perceived link between sediment and nutrient abundance in streams, sediment-parameter data at these sites were correlated to total-nitrogen and total-phosphorus concentrations. A significant relation ( $p$-value $<0.05$ ) was found between monitored nutrient concentrations and coincident sediment abundance, although there were no clear linear relations.

This compilation of data showed that SSC was monitored at 118 sites in Kentucky at some time between 1950 and 2008. As of March 2008, 9 sites were monitored for SSC in Kentucky ( 8 of which are new) down from a high of more than $60 \mathrm{SSC}$ sites during the 1980s. Of these $118 \mathrm{SSC}$ sites, 21 sites were also monitored for TSS; there are coincident records for both SSC and TSS at 6 sites. Forty-seven of these long-term water-quality sites were also monitored for turbidity; there are coincident records for SSC and turbidity at 42 sites, including all of those at which there are coincident data for TSS. The number of sites at which SSC and at least one other sediment parameter (TSS or turbidity) were monitored decreased from a high of 27 in 1987 to zero during the period 2001-2005.

\section{Introduction}

Water-quality data, including nitrogen and phosphorus concentrations, are used to model the contribution of individual streams to regional ecosystems to address concerns such as hypoxia in the Gulf of Mexico (Alexander and others, 2008). More recently, sediment is being included in this type of regional modeling (Schwarz, 2008). However, these regional modeling efforts are dependent upon the maintenance of long-term data-collection sites where the period of record encompasses changes in urban development and agricultural management, as well as potential climate change.

Three sediment parameters have been historically reported by the U.S. Geological Survey (USGS): suspendedsediment concentration (SSC), total suspended solids (TSS), and turbidity. Of these sediment parameters, SSC (National Water Information System (NWIS) parameter 80154 (p80154)) is preferred to TSS (p00530) because the analytical method for SSC has been shown to be the more precise and accurate method, resulting in less error in sediment-load estimates (Glysson and Gray, 2002). An intact sample is used to determine SSC, in contrast to an aliquot of the sample as used with TSS methods. In comparison to turbidity, SSC is accurate at all magnitudes of sediment concentration (milligram per liter). Turbidity (p00076), until recently, had an upper limit of approximately 1,000 nephelometric turbidity units (NTU) due to instrument limitations; turbidity also measures suspended materials in addition to sediment, including finely divided organic matter, plankton and other microscopic organisms, organic acids, and dyes (Anderson, 2005). Finally, use of different turbidimeter technologies can result in different turbidity measurements for the same environmental conditions or laboratory samples, yet all turbidity data were reported in the NWIS as a single parameter code, p00076, until 2005 (Miller, 2004); this complicates not only comparison of turbidity to SSC but also comparison of turbidity data among monitoring sites and data-collection periods (Sadar, 2002; Ziegler, 2002). 
Although SSC is the preferred sediment parameter and is the one traditionally monitored by the USGS, measurement and reporting of additional sediment parameters can have substantial research benefits. Specifically, because TSS and turbidity are frequently reported by other agencies (for example, Kentucky Division of Water; http://www.water.ky.gov/ sw/swmonitor/) the maintenance of multiparameter sediment sites enables extension of sediment modeling to more streams, including those of different orders and in different physiographic terranes. Consequently, it is important to understand the quantitative relation among these three sediment parameters. In order to maintain this ability to compare and contrast these different sediment parameters, it is critical that long-term records of all three parameters be available. The purpose of the data inventory and statistical analysis described in this report was to determine the availability of long-term sediment data for Kentucky and to quantify the relation among these three sediment parameters (SSC, TSS, and turbidity). The study was done in cooperation with the U.S. Environmental Protection Agency.

\section{Methods}

During January 2008, data were downloaded from the National Water Information System (NWIS; http://waterdata. usgs.gov/nwis/rt) for sites along Kentucky streams where long-term water-quality records were available. For purposes of this analysis, "long-term records" are defined as those from sites where 25 or more field visits had been made for collection of water-quality samples. Fewer than 25 sediment records may be available, however, if sediment was not on the sampling and analytical schedule for every field visit. The number of field visits per year depends on the particular site and sampling program.

From these retrieved observations, data for SSC (p80154), TSS (p00530), and turbidity (p00076) were inventoried in order to assess the abundance, history, and coordination of observations. Each sediment parameter was statistically described, and stepwise linear regression was used to develop a relation between SSC (the preferred parameter) and the surrogates TSS and/or turbidity using coincident observations (from the same site, day, and time) of the sediment parameters and instantaneous stream discharge (p00061). The correlation between individual sediment parameters, as well as to total nitrogen (p00600) and total phosphorus (p00665), was evaluated with scatterplots because of the perceived relation between sediment and nutrient abundance in streams; the significance of these correlations was tested with the Pearson's product-moment correlation coefficient. All statistical analyses were done with S-plus (Insightful Corporation, 2008).

\section{Sediment Data Inventory}

In Kentucky, SSC was monitored at 118 long-term sites between 1950 and 2008 [fig. 1 and table 1 (at the end of the report)]. More than 60 sites were monitored in the early 1980s; however, this number decreased to approximately 30 sites around 1982 and decreased again in the 1990s to less than 15 SSC sites (fig. 2). During the late 1990s, SSC was monitored at one site. As of December 2007, 10 sites were monitored for SSC in Kentucky. Of these 10 SSC sites, 8 are in watersheds that are the focus of recent interest (2007) by agencies that cooperate with the USGS in water-resources investigations (U.S. Environmental Protection Agency and Kentucky Division of Water). Collection of SSC data at the Green River at Munfordville, Ky. (USGS site ID 03308500, cover photo), was discontinued in February 2008. Currently, a long-term SSC record is maintained for the Tennessee River at Highway 60 near Paducah, Ky. (USGS site ID 03609750), at the confluence of the Tennessee and Ohio Rivers; flow at this site is regulated by the dam at Kentucky Lake, so highdischarge events, and the resultant sediment concentrations, are attenuated.

Total suspended sediment (TSS) was monitored at 21 of these 118 long-term sites where SSC was monitored (figs. 1 and 3 and table 1); 6 sites have coincident records for SSC and TSS (fig. 4). The number of TSS sites also peaked around 1980 with a maximum of 11 . By 1990, TSS was no longer monitored by the USGS.

Turbidity was monitored at 47 of these 118 long-term sites (figs. 1 and 5 and table 1), and there are coincident records of SSC and turbidity at 42 of these sites (fig. 6), including all of those at which there are coincident data for TSS. The number of turbidity sites peaked in the mid-1980s with a maximum of 20. This number began to decrease in the late1980s and, by 2001, the last p00076 turbidity record was discontinued. During 2007, SSC and turbidity were coincidently monitored on the Tennessee River at Highway 60 near Paducah, Ky. (USGS site ID 03609750), and the Cumberland River at Smithland, Ky. (USGS site ID 03438500); however, these data are not included in this report because a different turbidity unit (p63676) was used. [Details on USGS changes in turbidity measurement and reporting can be found in Miller (2004) and documents referenced therein.]

The number of monitored sites where SSC and at least one other sediment parameter were reported ranged from a high of 25 in 1987 to a low of zero during 2001-5. As of March 2008, nine sites were sampled for SSC data, and turbidity was monitored at one of these sites, the Tennessee River at Highway 60 near Paducah, Ky. (USGS site ID 03609750). 


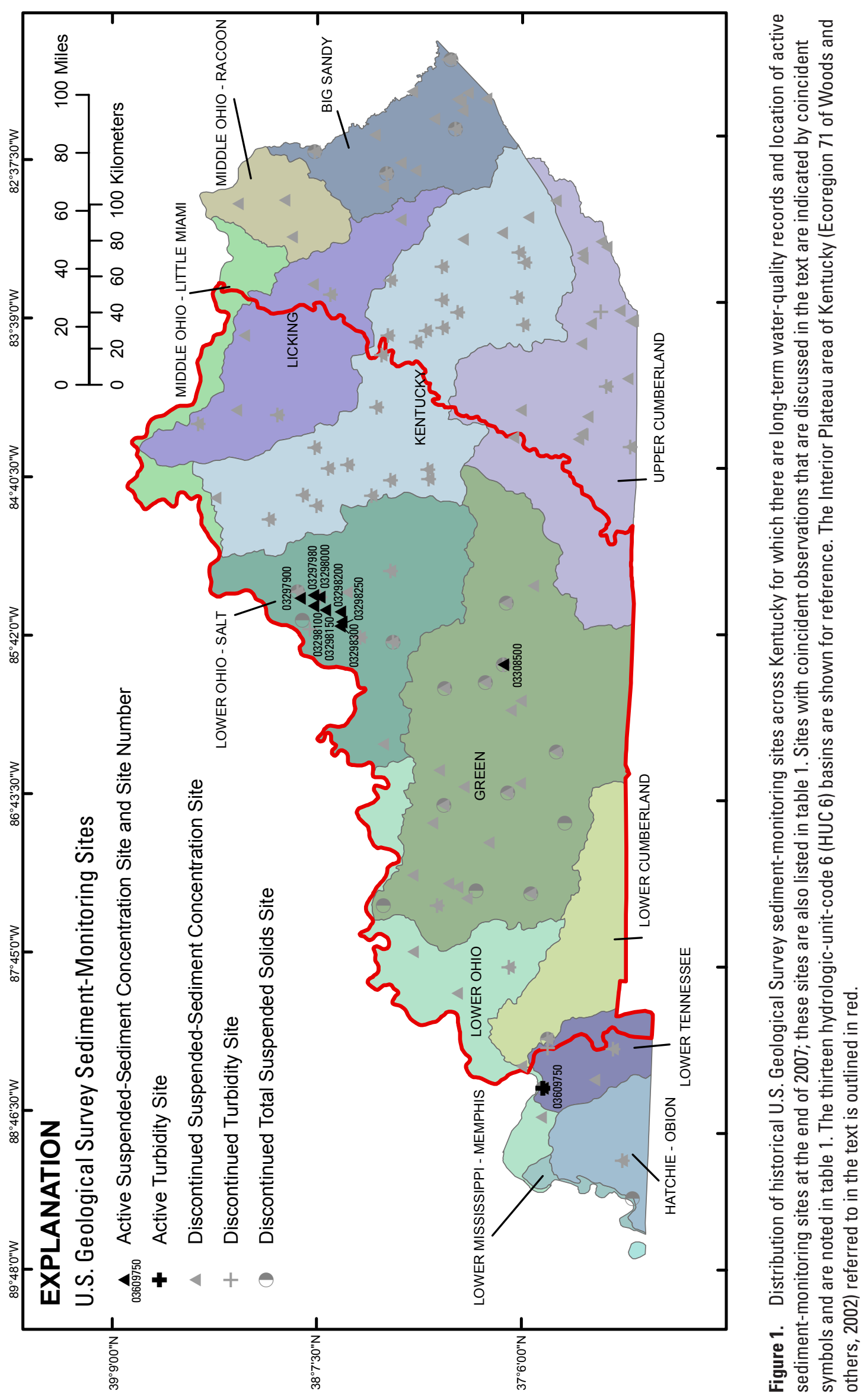




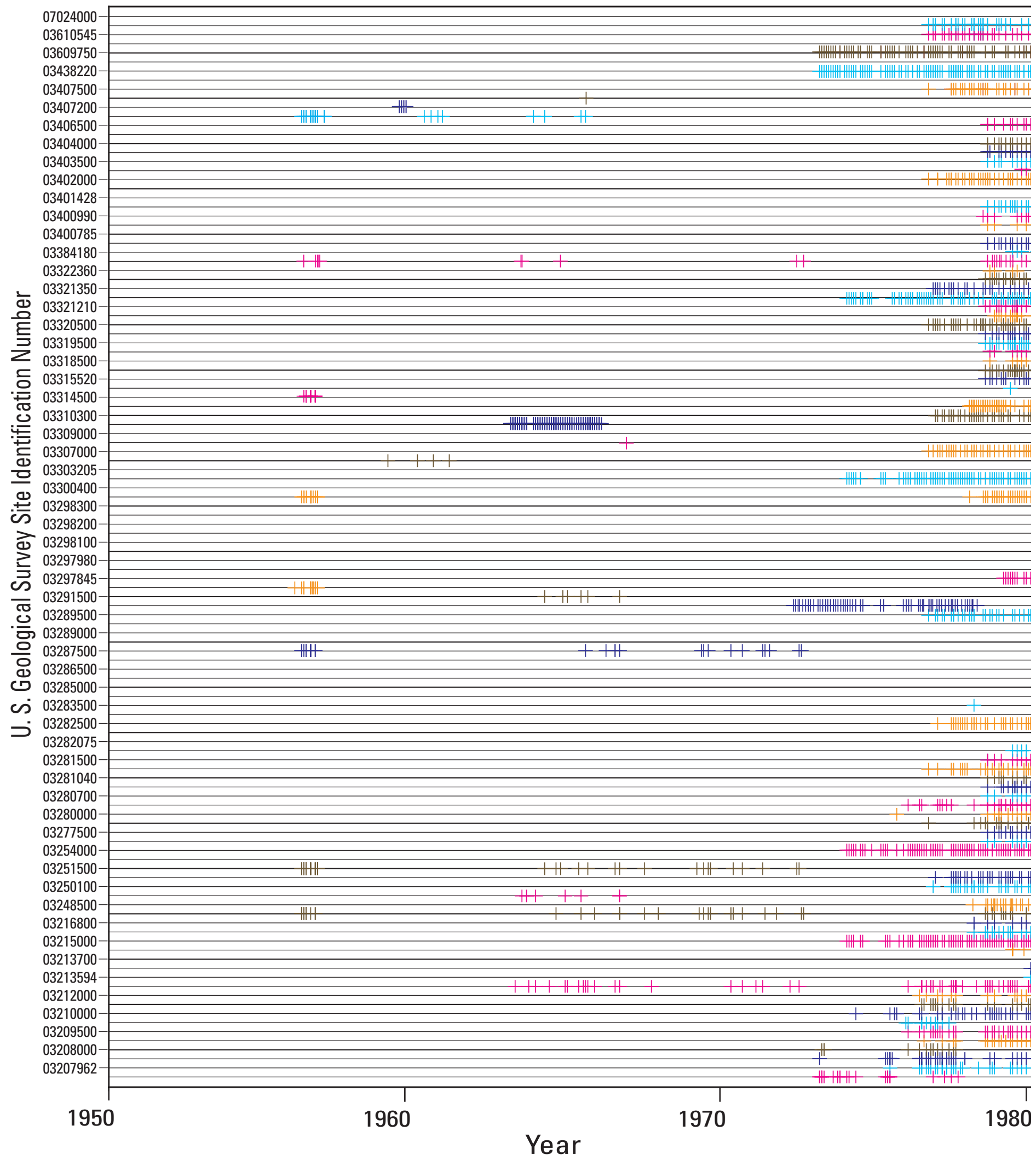

Figure 2. Sample-collection dates of suspended-sediment concentration at U.S. Geological Survey sites in Kentucky for which there are long-term water-quality records. The highest number of sites was monitored in the early 1980s; however, this number was halved by 1982 (shown by the first line). Some new sites were added in the mid-1980s, but the total number of sites was halved again 


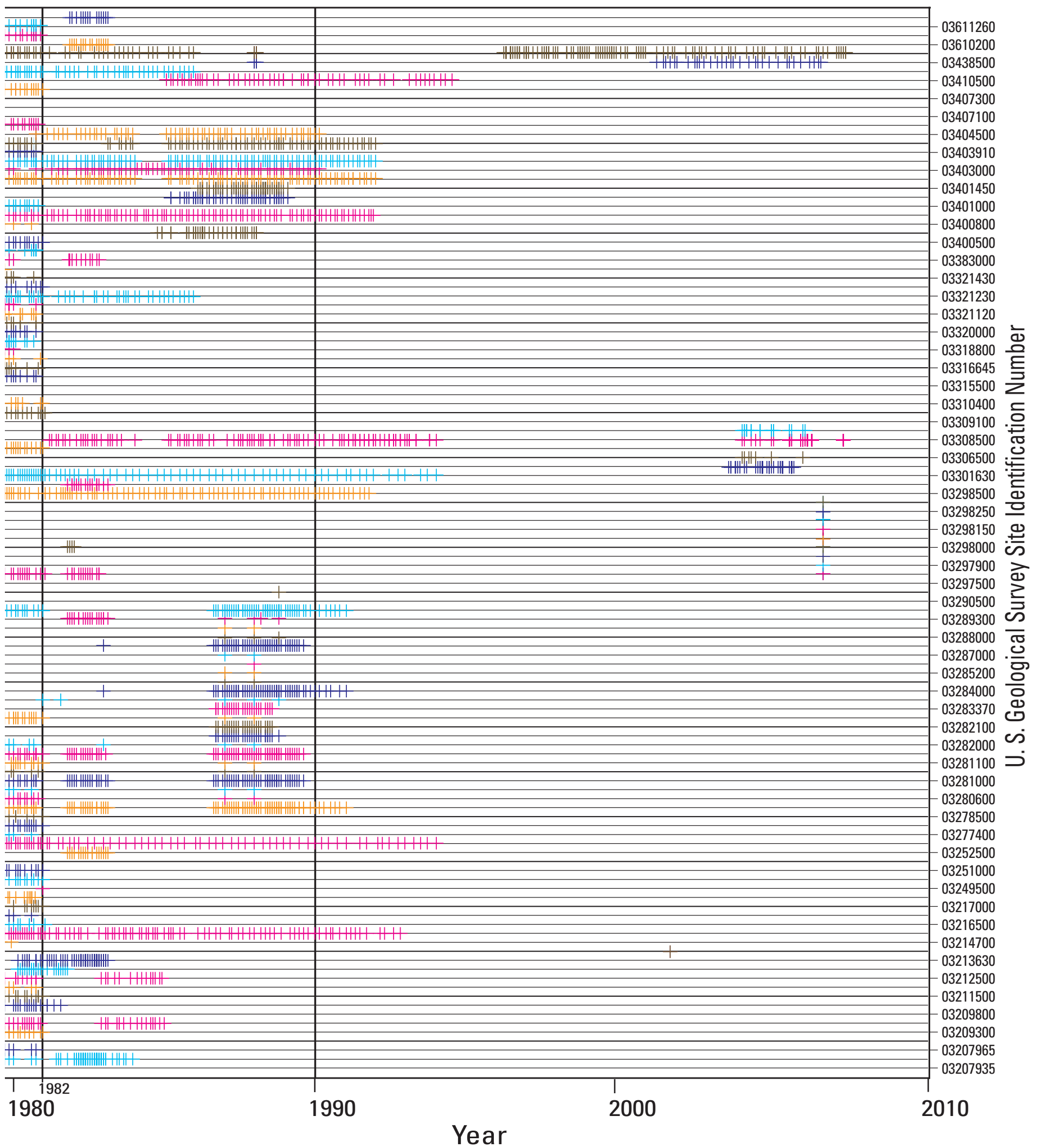

(to approximately 15) before 1990 (shown by the second line). The number of sites continued to decrease during the 1990s. At the end of 2007, 10 sites were being monitored in the Commonwealth; however, most of these have no long-term record. Each crosshatch (+) indicates a single sample date. Color in this figure is only to help the reader and is not meant to imply a difference between sites. 


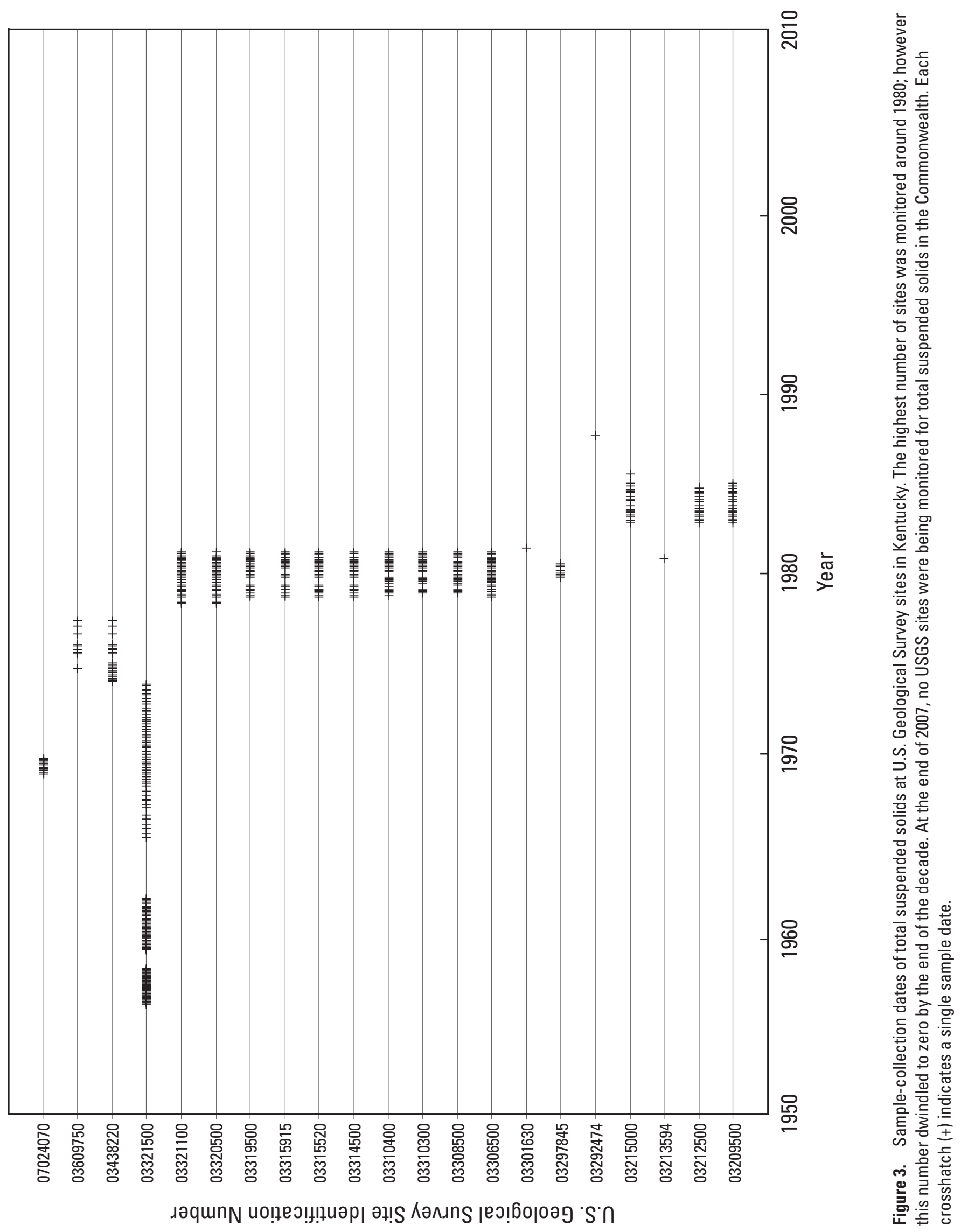




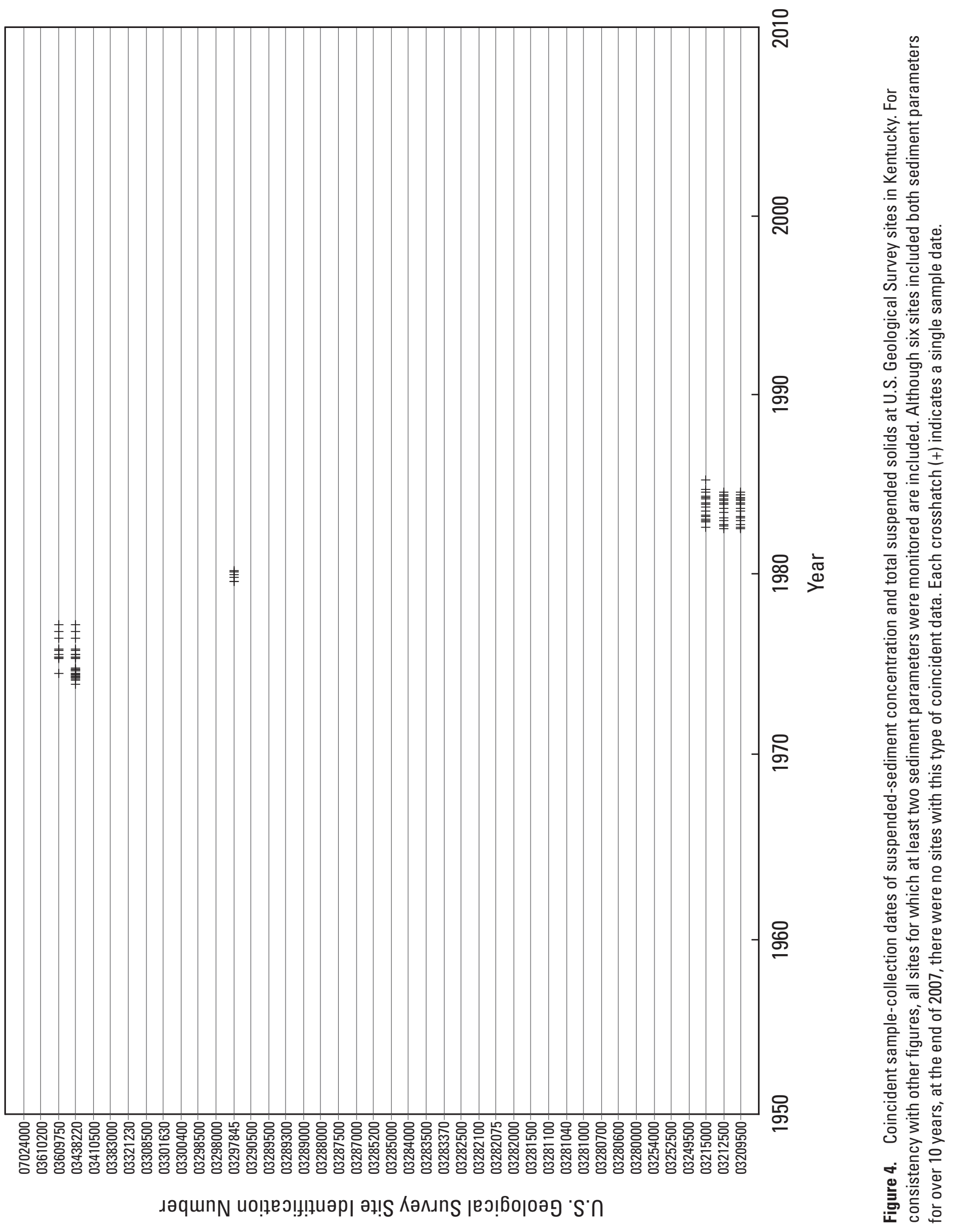



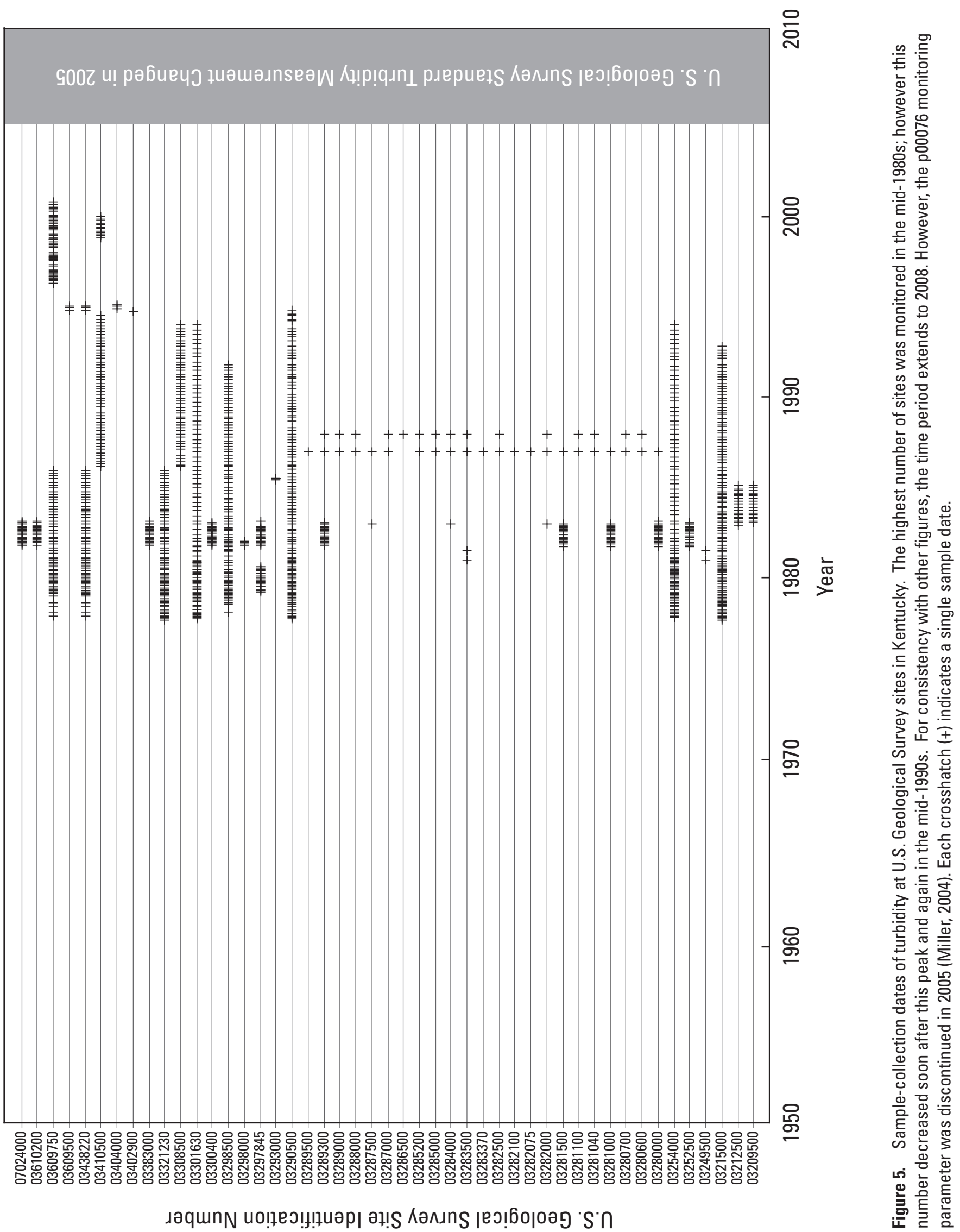


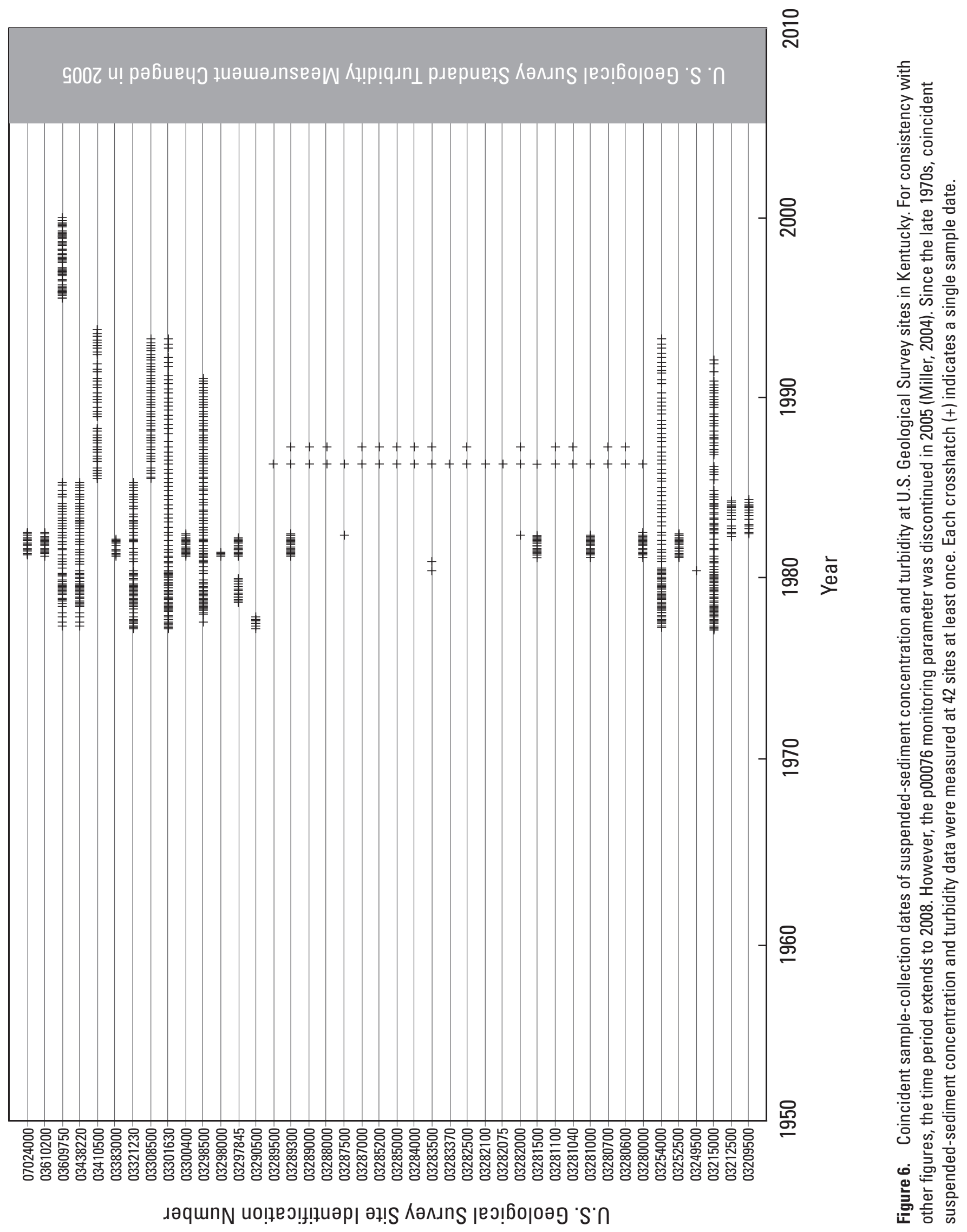




\section{Statistical Analysis of Selected Sediment and Nutrient Parameters}

Five water-quality parameters-SSC, TSS, turbidity, total nitrogen (TN), and total phosphorus (TP) - were statistically summarized to reveal any significant relation among them (table 2 and figs. 7-12). The nutrient parameters TN and TP were included in the statistical analysis because of the perceived relation between sediment and nutrient abundance in streams (as mentioned, for example, by Alexander and others, 2008). For the 42 stations at which there are coincident data for at least two sediment parameters, a Pearson's product-moment correlation was calculated. This analysis showed significant correlation between all pairs of sediment parameters and between the nutrient parameters. In addition, there was significant correlation between all sediment and nutrient parameters except for the total phosphorus and TSS pairing (fig. 12). The significance, however, is likely due to the large number of observations; visual inspection shows that none of the scatterplots shows a linear relation, and the correlations between sediment and nutrient parameters are all $<0.4$. Correlation between water-quality parameters also was evaluated separately for those sites that are part of the Interior Plateau area of Kentucky (red outline in fig. 1), which includes the Bluegrass and Pennyroyal karst terranes (Ecoregion 71 of Woods and others, 2002). Results from this analysis were similar (fig. 12; correlation coefficients in parentheses), with significant correlation between sediment parameters and between nutrient parameters; however, for sites in the Interior Plateau area of Kentucky, the correlation between SSC and total phosphorus is the only significant relation between an individual sediment parameter and a nutrient parameter.

In order to quantify the significant correlations between SSC and the surrogates TSS and/or turbidity, coincident observations were used in stepwise linear regression (table 3). These coincident observations ranged from 1 to $400 \mathrm{mg} / \mathrm{L}$ suspended sediment (recorded as p80154, SSC). Previous researchers have shown a natural (or Napierian) logarithm transformation to make the regressions more rigorous (Galloway and others, 2005) and this was true when either TSS or turbidity were individually used to estimate SSC. For sites with coincident observations of all three sediment parameters, the combination of TSS, turbidity, and instantaneous discharge was the strongest estimator of SSC; in this case, the untransformed values were the most rigorous indicators.

Each of these regressions of SSC on TSS and turbidity (table 3 ) is highly significant, and all coefficients retained are significant at the 0.05 confidence level. Although this indicates a significant ability to estimate SSC for streams in Kentucky from the surrogates TSS and turbidity, this ability is strongest when coincident TSS and turbidity data are available. The TSS slope coefficient was expected to be close to 1 because SSC and TSS are reported with the same units and should quantify the same material. Finally, although the regression of SSC on turbidity is significant, the relatively low $\mathrm{R}^{2}$ combined with the high number of observations suggests that estimates of SSC from this equation may be less accurate than those derived from TSS data.

Glysson and Gray (2002) noted that estimation of SSC sediment loads from other sediment parameters was most successful when data from individual stations were separated. Consequently, these regressions were assessed for all sites with $\geq 5$ coincident observations of different sediment parameters (tables 4, 5, and 6). Although some of these regressions are more rigorous, not all of the regressions are significant, and there is no clear pattern of significance with respect to sample size or coefficient values. The resulting slope $(\beta)$ coefficients also are inconsistent within each set of equations. Furthermore, site-specific analyses are prohibitive when trying to develop an SSC database for all of Kentucky due not only to the lack of coincident samples but also to the complexity of treating each site differently in regional modeling. 
Table 2. Statistical summary of selected water-quality parameters for sites where suspendedsediment concentration and at least one other sediment parameter were coincidentally monitored.

[SSC, suspended-sediment concentration; TSS, total suspended solids; $n$, number of coincident observations, not the number of matched sites; $p$, parameter; mg/L, milligrams per liter; NTU, nephelometric turbidity units]

\begin{tabular}{lccccr}
\hline $\begin{array}{c}\text { Parameter name and USGS NWIS } \\
\text { parameter code }\end{array}$ & Unit & Mean & $\begin{array}{c}\text { Standard } \\
\text { deviation }\end{array}$ & Range & n \\
\hline SSC - p80154 & $\mathrm{mg} / \mathrm{L}$ & 161 & 413 & 0.9 to 10,600 & 2,429 \\
TSS - p00530 & $\mathrm{mg} / \mathrm{L}$ & 48 & 67 & 1 to 396 & 75 \\
Turbidity - p00076 & $\mathrm{NTU}$ & 28 & 46 & .2 to 350 & 943 \\
Total nitrogen - p00600 & $\mathrm{mg} / \mathrm{L}$ & 1.5 & 1.7 & .2 to 26.0 & 1,333 \\
Total phosphorus - p00665 & $\mathrm{mg} / \mathrm{L}$ & .2 & .4 & .0 to 8.0 & 1,488 \\
\hline
\end{tabular}

Table 3. Regression of suspended-sediment concentration on total suspended solids, turbidity, and discharge.

[SSC, suspended-sediment concentration; TSS, total suspended solids; Q, instantaneous discharge; $n$, number of coincident observations, not the number of matched sites; ln, natural or Napierian logarithm; $\mathrm{R}^{2}$, coefficient of determination for equation; *, regression significant at the 0.05 confidence level]

\begin{tabular}{lrrc}
\hline \multicolumn{1}{c}{ Equation } & $\mathbf{n}$ & $\mathbf{R}^{2}$ & p-value \\
\hline $\ln \mathrm{SSC}=0.43+0.940 \ln$ TSS & 73 & $0.76^{*}$ & 0.000 \\
$\ln \mathrm{SSC}=1.59+0.638 \ln$ Turbidity $+0.046 \ln \mathrm{Q}$ & 933 & $.53^{*}$ & .000 \\
$\mathrm{SSC}=7.5+0.73 \mathrm{TSS}+0.88$ Turbidity $+0.006 \mathrm{Q}$ & 45 & $.92^{*}$ & .000 \\
\hline
\end{tabular}

Table 4. Regression of suspended-sediment concentration on total suspended solids for individual sites. Each regression takes the form In SSC $=$ intercept $+\beta_{\text {TSS }}$ In TSS.

[USGS, U.S. Geological Survey; ID, identification; $\beta$, slope coefficient; SSC, suspended-sediment concentration; TSS, total suspended solids; $\mathrm{n}$, number of coincident observations, not the number of matched sites; ln, natural or Napierian logarithm; $\mathrm{R}^{2}$, coefficient of determination for equation; ${ }^{*}$, coefficient is significant at the 0.05 confidence level]

\begin{tabular}{lccccc}
\hline \multicolumn{1}{c}{ USGS site ID } & Intercept & $\boldsymbol{\beta}_{\text {TSS }}$ & $\mathbf{n}$ & $\mathbf{R}^{2}$ & p-value \\
\hline 03209500 & $1.31^{*}$ & $0.80^{*}$ & 14 & 0.81 & 0.000 \\
03212500 & $1.27^{*}$ & $.76^{*}$ & 14 & .95 & .000 \\
03215000 & -.10 & $1.08^{*}$ & 13 & .87 & .000 \\
03297845 & -1.52 & $1.55^{*}$ & 6 & .91 & .003 \\
03438220 & .38 & $.88^{*}$ & 17 & .38 & .008 \\
03609750 & $3.20^{*}$ & -.16 & 9 & .05 & .570 \\
\hline
\end{tabular}


Table 5. Regression of suspended-sediment concentration on turbidity and discharge for individual sites. Each regression takes the form In SSC $=$ intercept $+\beta_{\text {Turbidity }} \ln$ Turbidity $+\beta_{0} \ln 0$.

[USGS, U.S. Geological Survey; ID, identification; $\beta$, slope coefficient; SSC, suspended-sediment concentration; Q, instantaneous discharge; $n$, number of coincident observations, not the number of matched sites; 1 , natural or Napierian logarithm; $\mathrm{R}^{2}$, coefficient of determination for equation; *, coefficient is significant at the 0.05 confidence level]

\begin{tabular}{lcccccc}
\hline USGS site ID & Intercept & $\boldsymbol{\beta}_{\text {Turbidity }}$ & $\boldsymbol{\beta}_{\mathbf{0}}$ & $\mathbf{n}$ & $\mathbf{R}^{2}$ & p-value \\
\hline 03209500 & 1.92 & $0.27^{*}$ & 0.24 & 14 & 0.72 & 0.001 \\
03212500 & 2.39 & $.49^{*}$ & .08 & 14 & .71 & .001 \\
03215000 & -.43 & $.50^{*}$ & $.40^{*}$ & 99 & .67 & .000 \\
03252500 & .61 & $.75^{*}$ & .11 & 17 & .77 & .000 \\
03254000 & .62 & $.43^{*}$ & $.27^{*}$ & 91 & .53 & .000 \\
03280000 & .78 & $1.16^{*}$ & -.08 & 17 & .95 & .000 \\
03281000 & 1.21 & $.40^{*}$ & .20 & 17 & .54 & .005 \\
03281500 & $1.41^{*}$ & $.94^{*}$ & -.12 & 17 & .83 & .000 \\
03289300 & $2.40^{*}$ & $.68^{*}$ & -.27 & 19 & .25 & .096 \\
03290500 & -1.34 & -.17 & $.73^{*}$ & 8 & .96 & .000 \\
03297845 & $2.23^{*}$ & $.29^{*}$ & $.23^{*}$ & 28 & .47 & .000 \\
03298500 & $.82^{*}$ & $.41^{*}$ & $.26^{*}$ & 94 & .65 & .000 \\
03300400 & .28 & $.79^{*}$ & .12 & 16 & .84 & .000 \\
03301630 & $1.96^{*}$ & $.35^{*}$ & $.22^{*}$ & 91 & .52 & .000 \\
03308500 & 1.09 & $.62^{*}$ & .13 & 47 & .60 & .000 \\
03321230 & .96 & $.19^{*}$ & $.30^{*}$ & 62 & .36 & .000 \\
03383000 & 1.08 & .71 & .08 & 10 & .51 & .083 \\
03410500 & -.47 & $.41^{*}$ & $.30^{*}$ & 41 & .54 & .000 \\
03438200 & $-2.72^{*}$ & .05 & $.53^{*}$ & 56 & .40 & .000 \\
03609750 & -.39 & .08 & .25 & 107 & .14 & .000 \\
03610200 & $1.42^{*}$ & $.64^{*}$ & .15 & 14 & .57 & .010 \\
07024000 & $1.75^{*}$ & $.63^{*}$ & .02 & 614 & .49 & .000 \\
\hline
\end{tabular}

Table 6. Regression of suspended-sediment concentration on total suspended solids, turbidity, and discharge for individual sites. Each regression takes the form SSC $=$ intercept $+\beta_{\text {TSS }}$ TSS $+\beta_{\text {Turbidity }}$ Turbidity $+\beta_{0} 0$.

[USGS, U.S. Geological Survey; ID, identification; $\beta$, slope coefficient; SSC, suspended-sediment concentration; TSS, total suspended solids; Q, instantaneous discharge; n, number of coincident observations, not the number of matched sites; $\mathrm{R}^{2}$, coefficient of determination for equation; *, coefficient is significant at the 0.05 confidence level]

\begin{tabular}{lccccccc}
\hline USGS site ID & Intercept & $\boldsymbol{\beta}_{\text {TSS }}$ & $\boldsymbol{\beta}_{\text {Turbidity }}$ & $\boldsymbol{\beta}_{\mathbf{0}}$ & $\mathbf{n}$ & $\mathbf{R}^{2}$ & p-value \\
\hline 03209500 & $15.92^{*}$ & 0.57 & 1.14 & $0.01^{*}$ & 13 & 0.97 & 0.000 \\
03212500 & 9.50 & $.82^{*}$ & $.75^{*}$ & .00 & 14 & .98 & .000 \\
03215000 & 1.35 & .51 & 1.39 & .01 & 12 & .89 & .000 \\
03297845 & -19.94 & 2.51 & -.04 & -.15 & 6 & .95 & .076 \\
\hline
\end{tabular}




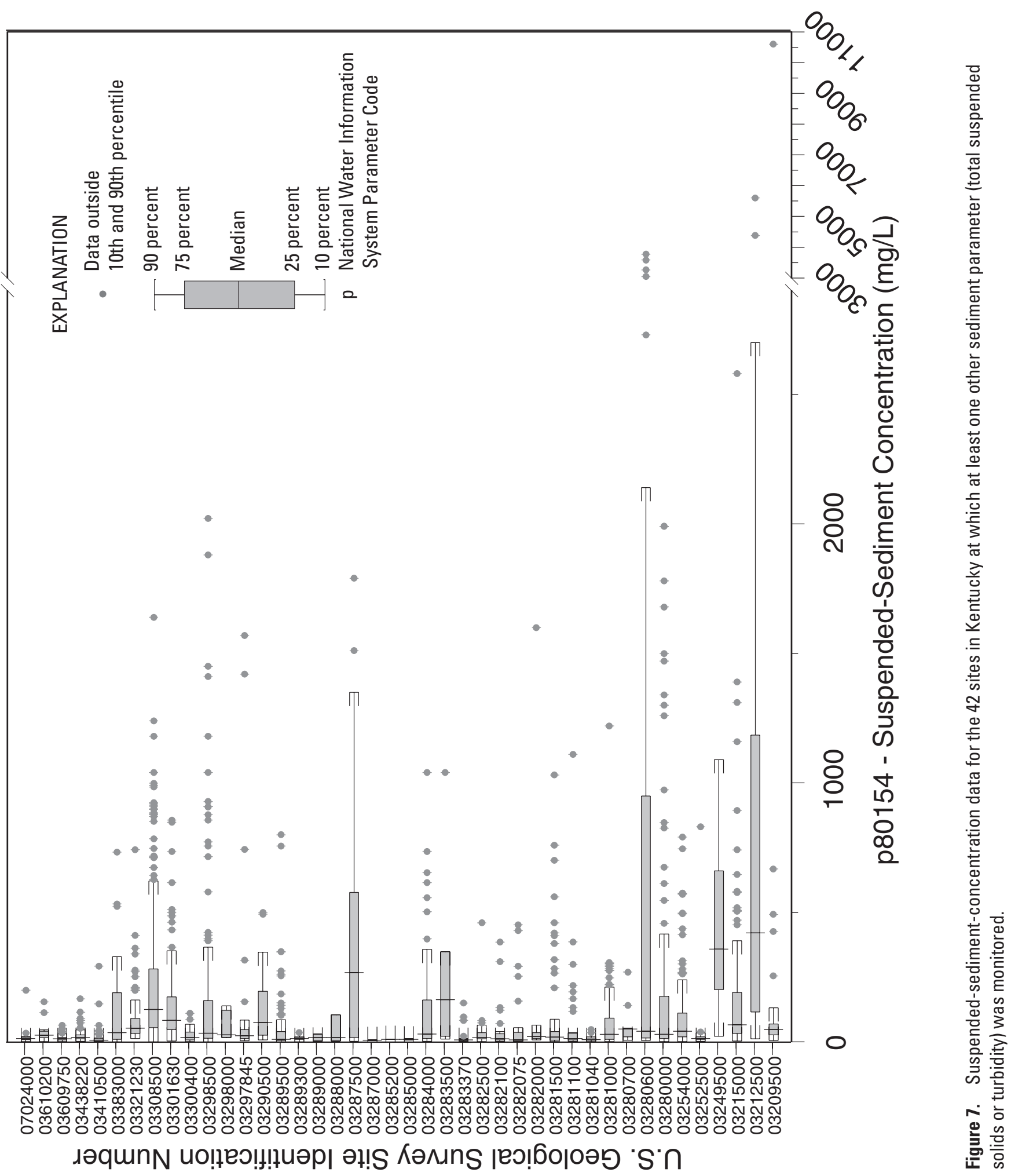




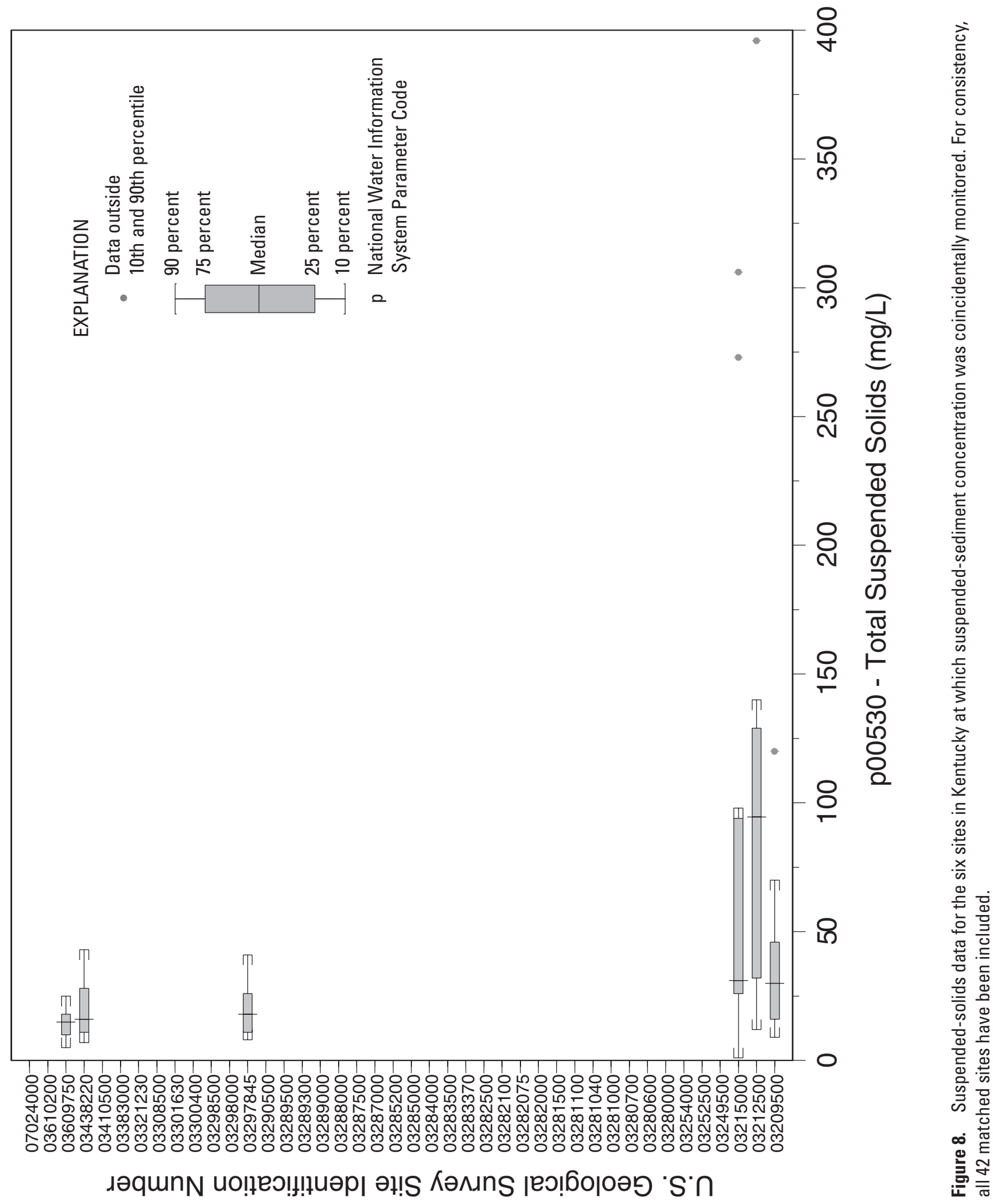




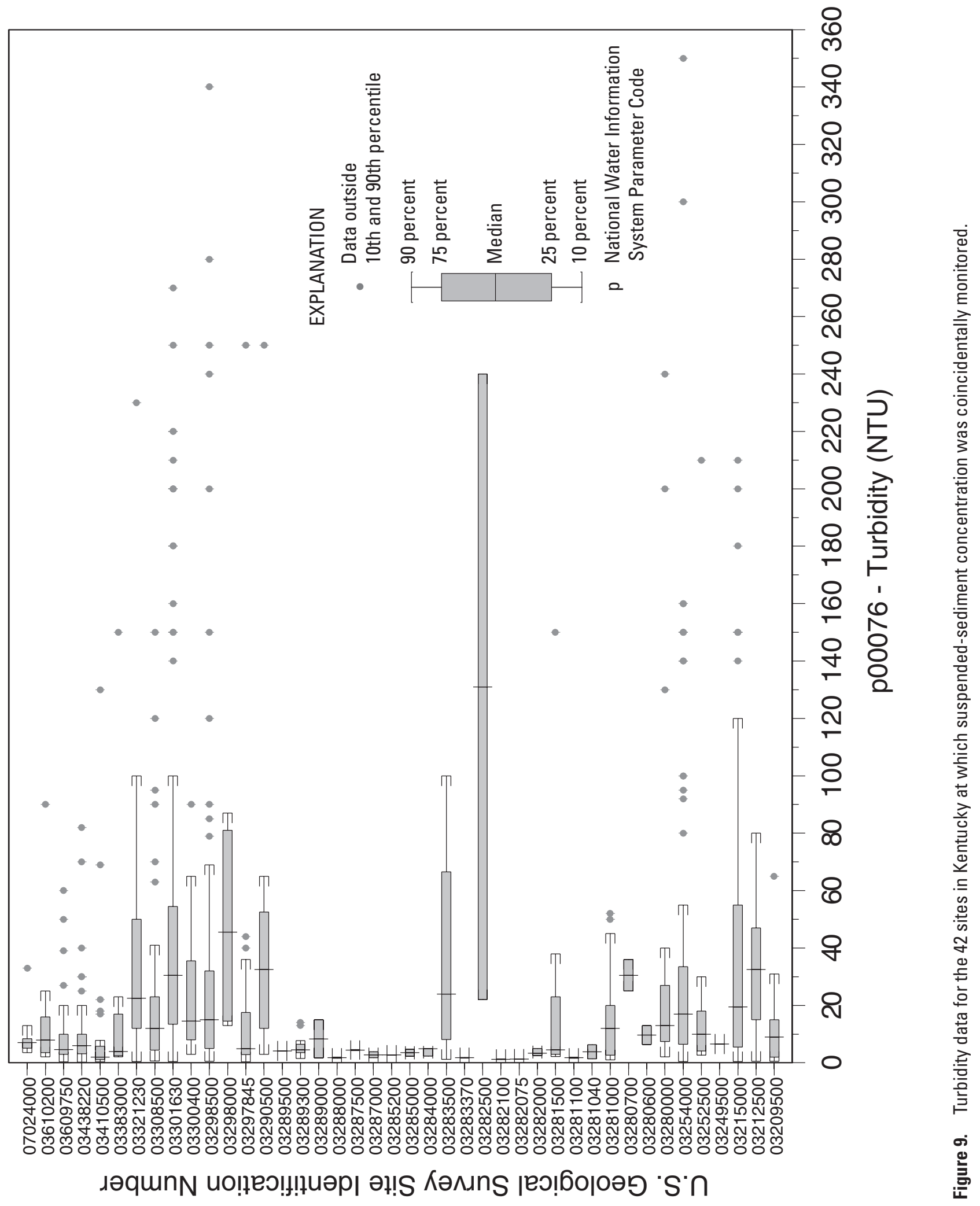




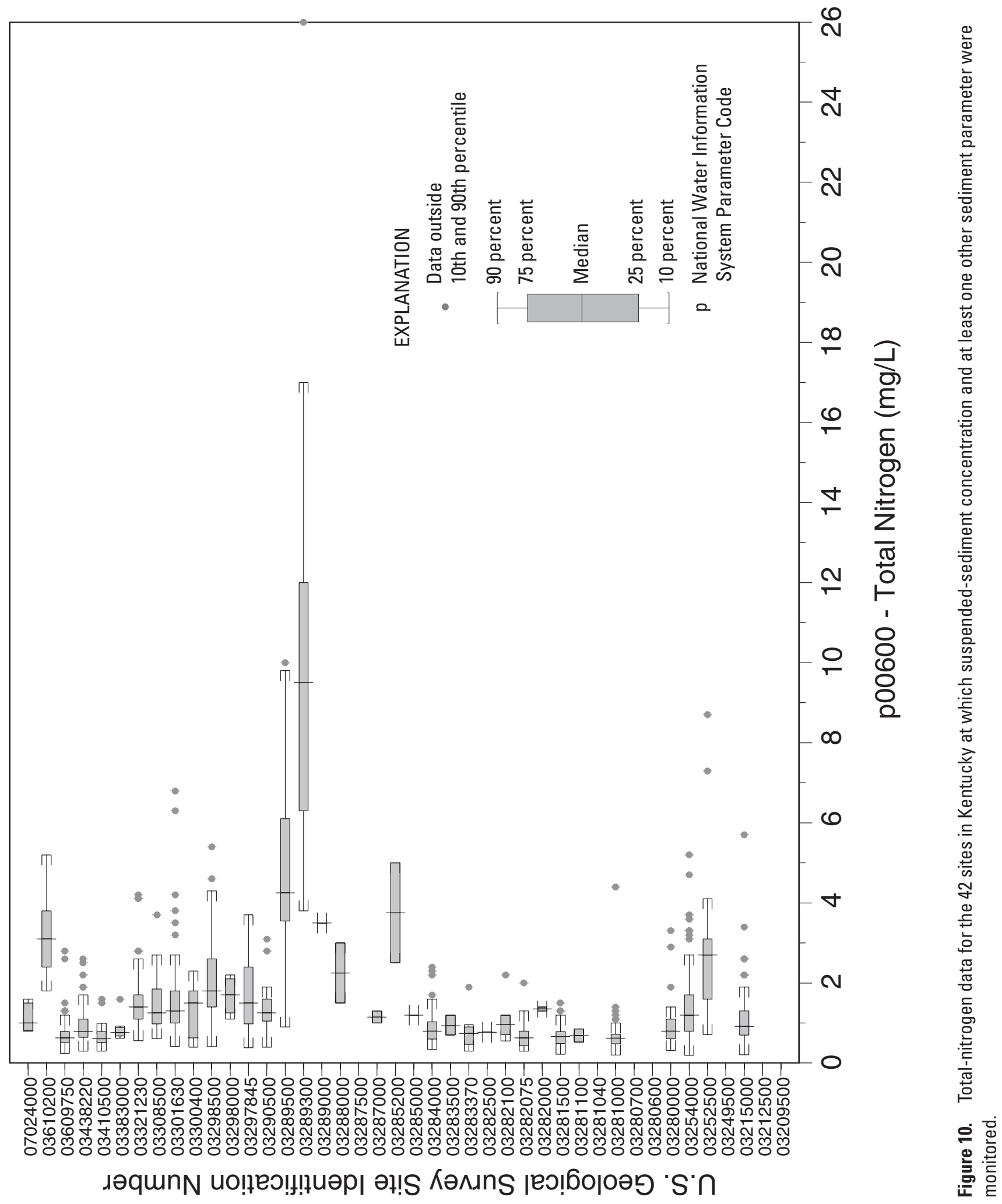




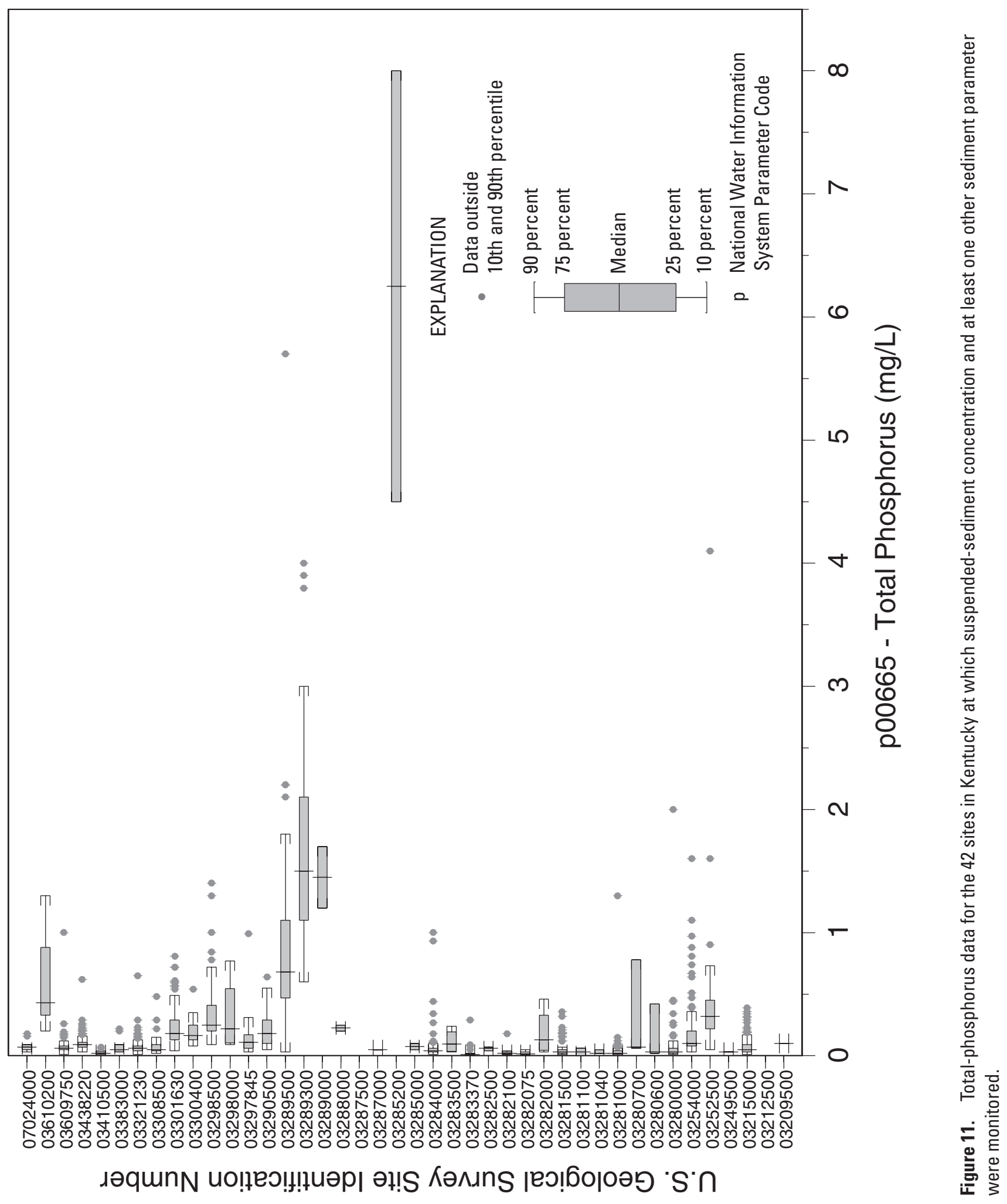




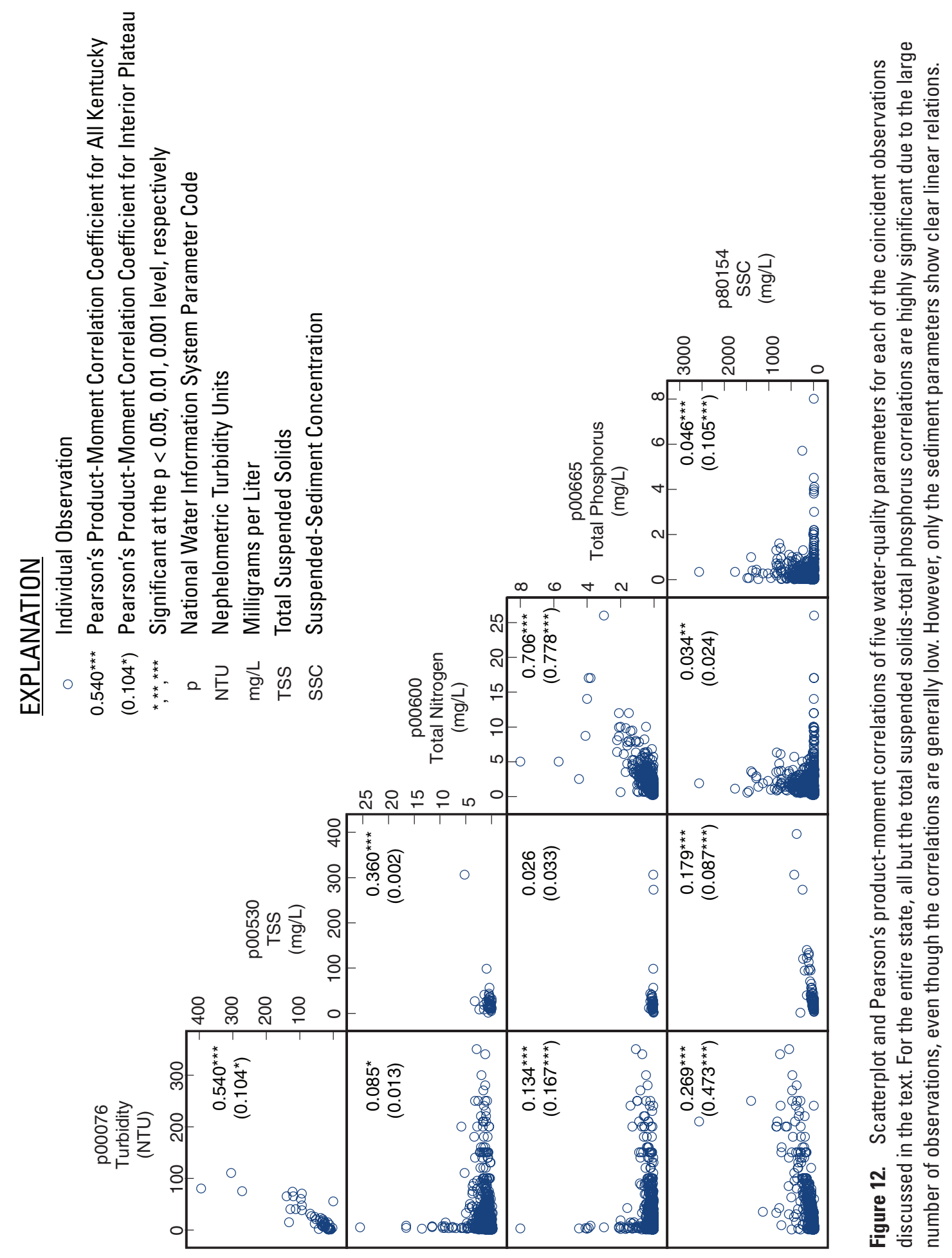




\section{Summary}

An inventory and statistical analysis of sediment data for Kentucky streams was completed by the USGS, in cooperation with the U.S. Environmental Protection Agency, to assess the availability and quantify the statistical relations among suspended-sediment concentration (SSC) and the surrogate sediment parameters total suspended solids (TSS) and turbidity for the period 1950-2008. The relation of sediment parameters to total nitrogen and total phosphorus was also quantified. Suspended-sediment concentration is significantly correlated to the two surrogate sediment parameters of TSS and turbidity, as well as to total nitrogen and total phosphorus. On the basis of this analysis, TSS and turbidity both can be used to statistically estimate SSC for runoff events and stream reaches where no SSC data are available. However, this analysis also shows that estimation will be stronger by use of TSS, as opposed to turbidity, and that these data should be weighted accordingly in any modeling efforts for which SSC is the preferred method. The strongest statistical estimate results from a combination of TSS and turbidity data.

This inventory has illustrated that sediment monitoring of all types has declined in Kentucky since the maximum number of sites in the early 1980s $(65,11$, and 20 sites for SSC, TSS, and turbidity, respectively). As of March 2008, SSC was monitored at nine sites; eight of these sites were started in 2007. The remaining site at which SSC was monitored is on a controlled stream reach, downstream from a reservoir, where high-flow events are attenuated. The result is that there are no remaining sites that can be used for modeling changes in sediment concentration due to climatic events or contemporary land-use changes, including urban development and agricultural management.

\section{References Cited}

Alexander, R.B., Smith, R.A., Schwarz, G.E., Boyer, E.W., Nolan, J.V., and Brakebill, J.W., 2008, Differences in phosphorus and nitrogen delivery to the Gulf of Mexico from the Mississippi River Basin: Environmental Science \& Technology, v. 42, no. 3, p. 822-830.

Anderson, C.W., 2005, Turbidity (version 2.1): U.S. Geological Survey Techniques of Water-Resources Investigations, book 9, chap. A6, section 6.7, 55 p., accessed September 16, 2008, at http://water.usgs.gov/owq/FieldManual/Chapter6/ Section6.7_v2.1.pdf

Galloway, J.M., Evans, D.A., and Green, W.R., 2005, Comparability of suspended-sediment concentration and total suspended-solids data for two sites on the L'Anguille River, Arkansas, 2001 to 2003: U.S. Geological Survey Scientific Investigations Report 2005-5193, 10 p.
Glysson, G.D., and Gray, J.R., 2002, Total suspended solids data for use in sediment studies, in Turbidity and other sediment surrogates workshop proceedings, April 30-May 2, 2002: Accessed September 16, 2008, at http://water.usgs. gov/osw/techniques/TSS/glysson.pdf

Insightful Corporation, 2008, S-plus 8: Boston, Mass., TIBCO Software Inc., available at $h t t p: / / w w w . i n s i g h t f u l . c o m /$ products/splus/default.asp

Miller, T.L., 2004, Revision of NFM Chapter 6, Section 6.7Turbidity: U.S. Geological Survey Office of Water Quality Technical Memorandum 2004.03 : Accessed September 16, 2008, at http://water.usgs.gov/admin/memo/QW/qw04.03. html

Sadar, Mike, 2002, Turbidity instrumentation-An overview of today's available technology, in Turbidity and other sediment surrogates workshop proceedings, April 30-May 2, 2002: Accessed September 16, 2008, at http://water.usgs. gov/osw/techniques/TSS/sadar.pdf

Schwarz, G.E., 2008, A preliminary SPARROW model of suspended sediment for the conterminous United States: U.S. Geological Survey Open-File Report 2008-1205, 8 p., accessed September 16, 2008, at http://pubs.usgs.gov/ of/2008/1205.

Woods, A.J., Omernik, J.M., Martin, W.H., Pond, G.J., Andrews, W.M., Call, S.M., Comstock, J.A., and Taylor, D.D., 2002, Ecoregions of Kentucky (color poster with map, descriptive text, summary tables, and photographs): Reston, Va., U.S. Geological Survey (map scale 1:1,000,000).

Ziegler, A.C., 2002, Issues related to use of turbidity measurements as a surrogate for suspended sediment, in Turbidity and other sediment surrogates workshop proceedings, April 30-May 2, 2002: Accessed September 16, 2008, at http://water.usgs.gov/osw/techniques/TSS/ZieglerT.pdf 
Table 1. Long-term stations where at least one parameter was monitored. Matched sites, with coincident SSC observations, are indicated by an * next to the second parameter.

[USGS, U.S. Geological Survey; ID, identification; SSC, suspended-sediment concentration; TSS, total suspended solids; p, parameter code]

\begin{tabular}{|c|c|c|c|c|c|c|}
\hline $\begin{array}{l}\text { USGS } \\
\text { site ID }\end{array}$ & Site name & $\begin{array}{c}\text { SSC } \\
\text { (p80154) }\end{array}$ & $\begin{array}{c}\text { TSS } \\
(p 00530)\end{array}$ & $\begin{array}{l}\text { Turbidity } \\
\text { (p00076) }\end{array}$ & $\begin{array}{c}\text { Total } \\
\text { nitrogen } \\
\text { (p00600) }\end{array}$ & $\begin{array}{c}\text { Total } \\
\text { phosphorus } \\
\text { (p00665) }\end{array}$ \\
\hline 03207935 & LICK CREEK AT LICK CREEK, KY & $\mathrm{x}$ & & & & \\
\hline 03207962 & DICKS FORK AT PHYLLIS, KY & $\mathrm{x}$ & & & & \\
\hline 03207965 & GRAPEVINE CREEK NEAR PHYLLIS, KY & $\mathrm{x}$ & & & & \\
\hline 03208000 & $\begin{array}{l}\text { LEVISA FORK BELOW FISHTRAP DAM NEAR } \\
\text { MILLARD, KY }\end{array}$ & $\mathrm{x}$ & & & & \\
\hline 03209300 & RUSSELL FORK AT ELKHORN CITY, KY & $\mathrm{x}$ & & & & \\
\hline 03209500 & LEVISA FORK AT PIKEVILLE, KY & $\mathrm{x}$ & $x^{*}$ & $x^{*}$ & & $x^{*}$ \\
\hline 03209800 & LEVISA FORK AT PRESTONSBURG, KY & $\mathrm{x}$ & & & & \\
\hline 03210000 & JOHNS CREEK NEAR META, KY & $\mathrm{x}$ & & & & \\
\hline 03211500 & JOHNS CREEK NEAR VAN LEAR, KY & $\mathrm{x}$ & & & & \\
\hline 03213594 & CAMP CREEK NEAR ARGO, KY & $\mathrm{x}$ & $\mathrm{x}$ & & & \\
\hline 03213630 & RIGHT FORK HURRICANE CREEK NEAR STOPOVER, KY & $\mathrm{x}$ & & & & \\
\hline 03213700 & TUG FORK AT WILLIAMSON, WV & $\mathrm{x}$ & & & & \\
\hline 03214700 & ROCKCASTLE CREEK AT INEZ, KY & $\mathrm{x}$ & & & & \\
\hline 03215000 & BIG SANDY RIVER AT LOUISA, KY & $\mathrm{x}$ & $\mathrm{x}^{*}$ & $x^{*}$ & $x^{*}$ & $x^{*}$ \\
\hline 03216500 & LITTLE SANDY RIVER AT GRAYSON, KY & $\mathrm{x}$ & & & & \\
\hline 03216800 & TYGARTS CREEK AT OLIVE HILL, KY & $\mathrm{x}$ & & & & \\
\hline 03217000 & TYGARTS CREEK NEAR GREENUP, KY & $\mathrm{x}$ & & & & \\
\hline 03248500 & LICKING RIVER NEAR SALYERSVILLE, KY & $\mathrm{x}$ & & & & \\
\hline 03277400 & LEATHERWOOD CREEK AT DAISY, KY & $\mathrm{x}$ & & & & \\
\hline 03277500 & NORTH FORK KENTUCKY RIVER AT HAZARD, KY & $\mathrm{x}$ & & & & $\mathrm{x}$ \\
\hline 03278500 & TROUBLESOME CREEK AT NOBLE, KY & $\mathrm{x}$ & & & & \\
\hline 03280000 & NORTH FORK KENTUCKY RIVER AT JACKSON, KY & $\mathrm{x}$ & & $x^{*}$ & $x^{*}$ & $\mathrm{x}^{*}$ \\
\hline 03280600 & MIDDLE FORK KENTUCKY RIVER NEAR HYDEN, KY & $\mathrm{x}$ & & $x^{*}$ & & $\mathrm{x}^{*}$ \\
\hline 03280700 & CUTSHIN CREEK AT WOOTON, KY & $\mathrm{x}$ & & $x^{*}$ & & $\mathrm{x}^{*}$ \\
\hline 03281000 & MIDDLE FORK KENTUCKY RIVER AT TALLEGA, KY & $\mathrm{x}$ & & $x^{*}$ & $\mathrm{x}^{*}$ & $\mathrm{x}^{*}$ \\
\hline 03281040 & RED BIRD RIVER NEAR BIG CREEK, KY & $\mathrm{x}$ & & $\mathrm{x}^{*}$ & & $x^{*}$ \\
\hline 03281100 & GOOSE CREEK AT MANCHESTER, KY & $\mathrm{x}$ & & $x^{*}$ & $x^{*}$ & $\mathrm{x}^{*}$ \\
\hline 03281500 & SOUTH FORK KENTUCKY RIVER AT BOONEVILLE, KY & $\mathrm{x}$ & & $x^{*}$ & $\mathrm{x}^{*}$ & $\mathrm{x}^{*}$ \\
\hline 03282000 & KENTUCKY RIVER AT LOCK 14 AT HEIDELBERG, KY & $\mathrm{x}$ & & $\mathrm{x}^{*}$ & $\mathrm{x}^{*}$ & $\mathrm{x}^{*}$ \\
\hline 03282075 & BIG SINKING CREEK NEAR CRYSTAL, KY & $\mathrm{x}$ & & $x^{*}$ & $\mathrm{x}^{*}$ & $x^{*}$ \\
\hline 03282100 & FURNACE FORK NEAR CRYSTAL , KY & $\mathrm{x}$ & & $x^{*}$ & $\mathrm{x}^{*}$ & $x^{*}$ \\
\hline
\end{tabular}


Table 1. Long-term stations where at least one parameter was monitored. Matched sites, with coincident SSC observations, are indicated by an * next to the second parameter - Continued

[USGS, U.S. Geological Survey; ID, identification; SSC, suspended-sediment concentration; TSS, total suspended solids; p, parameter code]

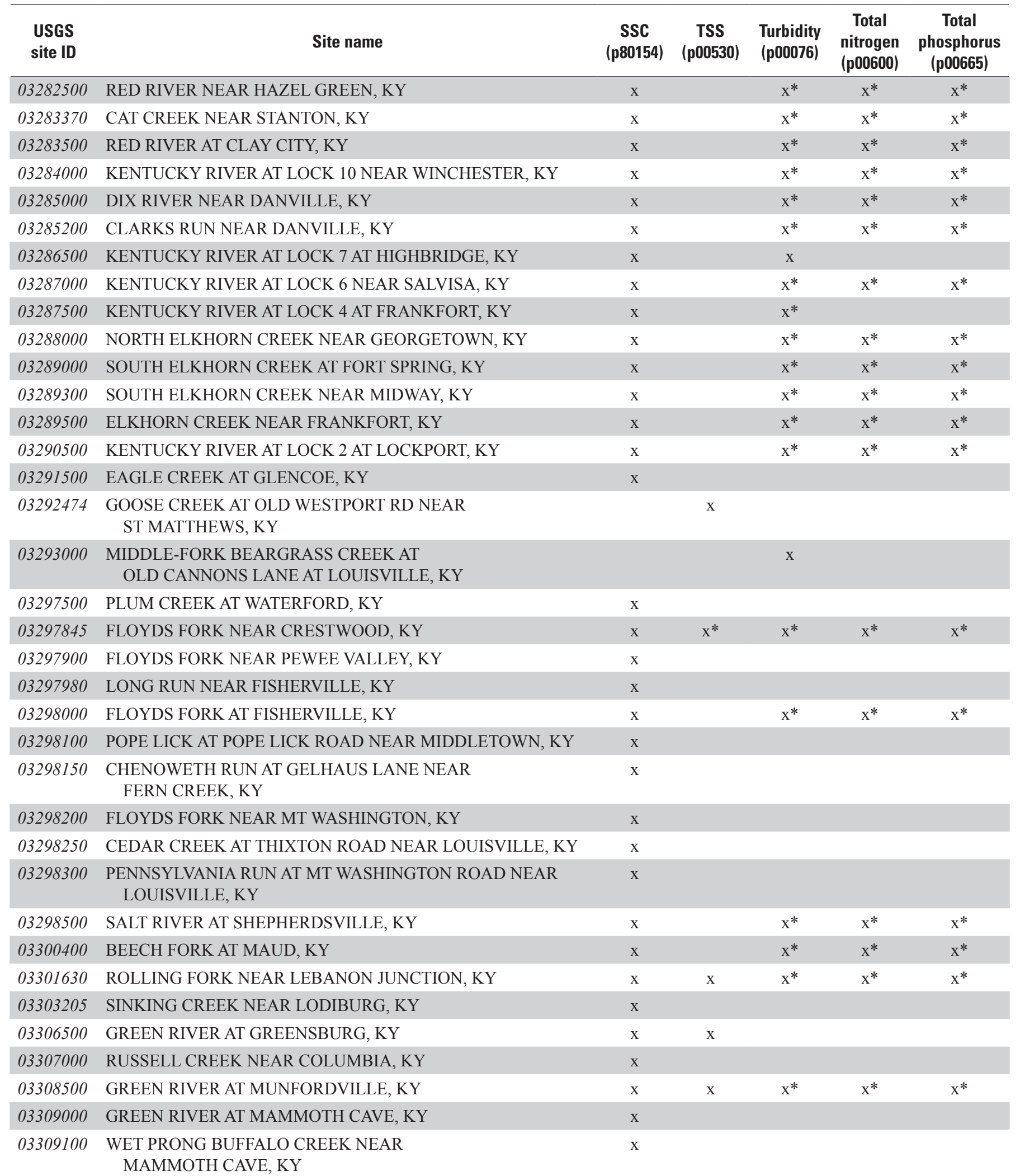


Table 1. Long-term stations where at least one parameter was monitored. Matched sites, with coincident SSC observations, are indicated by an * next to the second parameter - Continued

[USGS, U.S. Geological Survey; ID, identification; SSC, suspended-sediment concentration; TSS, total suspended solids; $p$, parameter code]

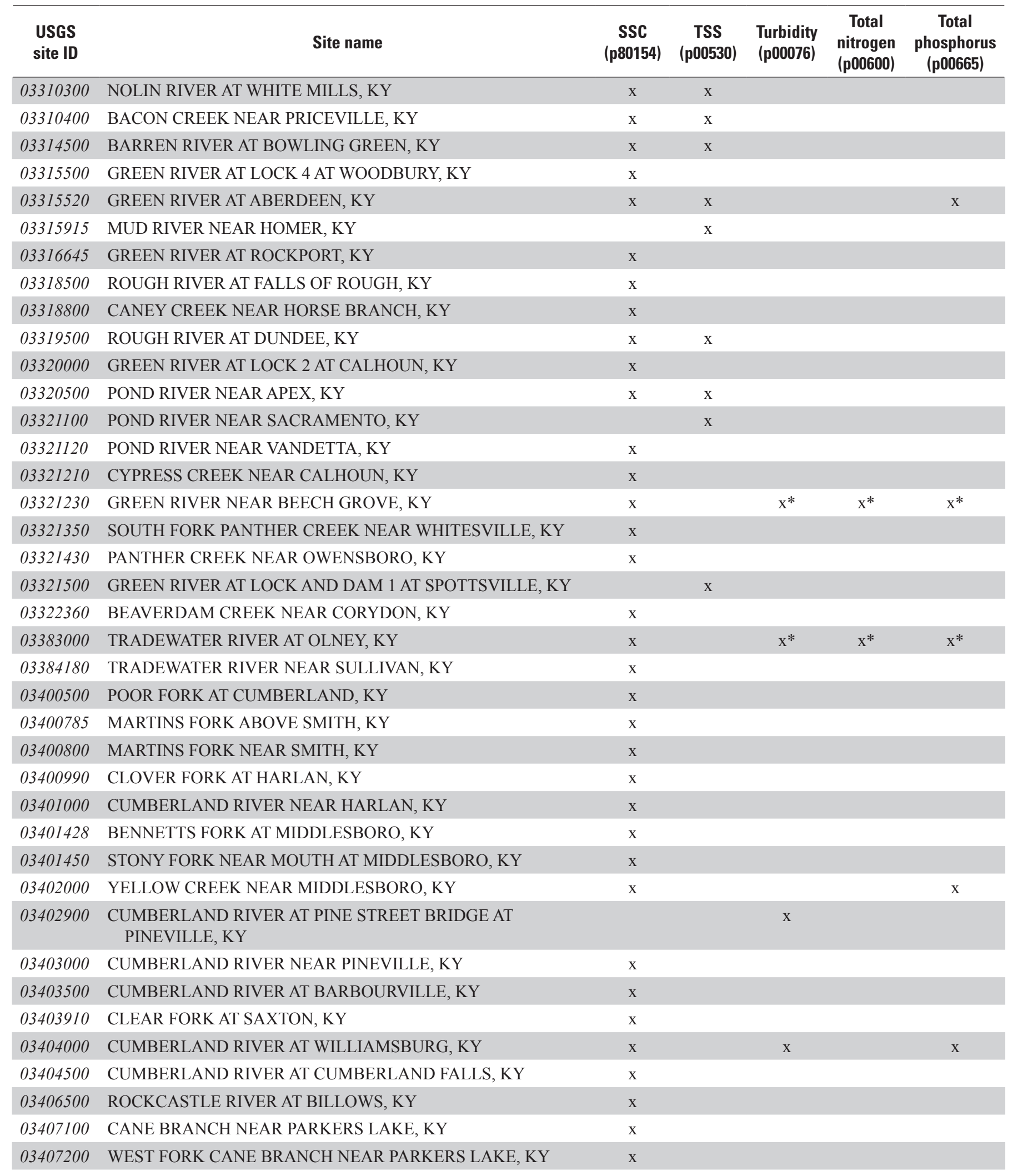


Table 1. Long-term stations where at least one parameter was monitored. Matched sites, with coincident SSC observations, are indicated by an * next to the second parameter-Continued

[USGS, U.S. Geological Survey; ID, identification; SSC, suspended-sediment concentration; TSS, total suspended solids; $p$, parameter code]

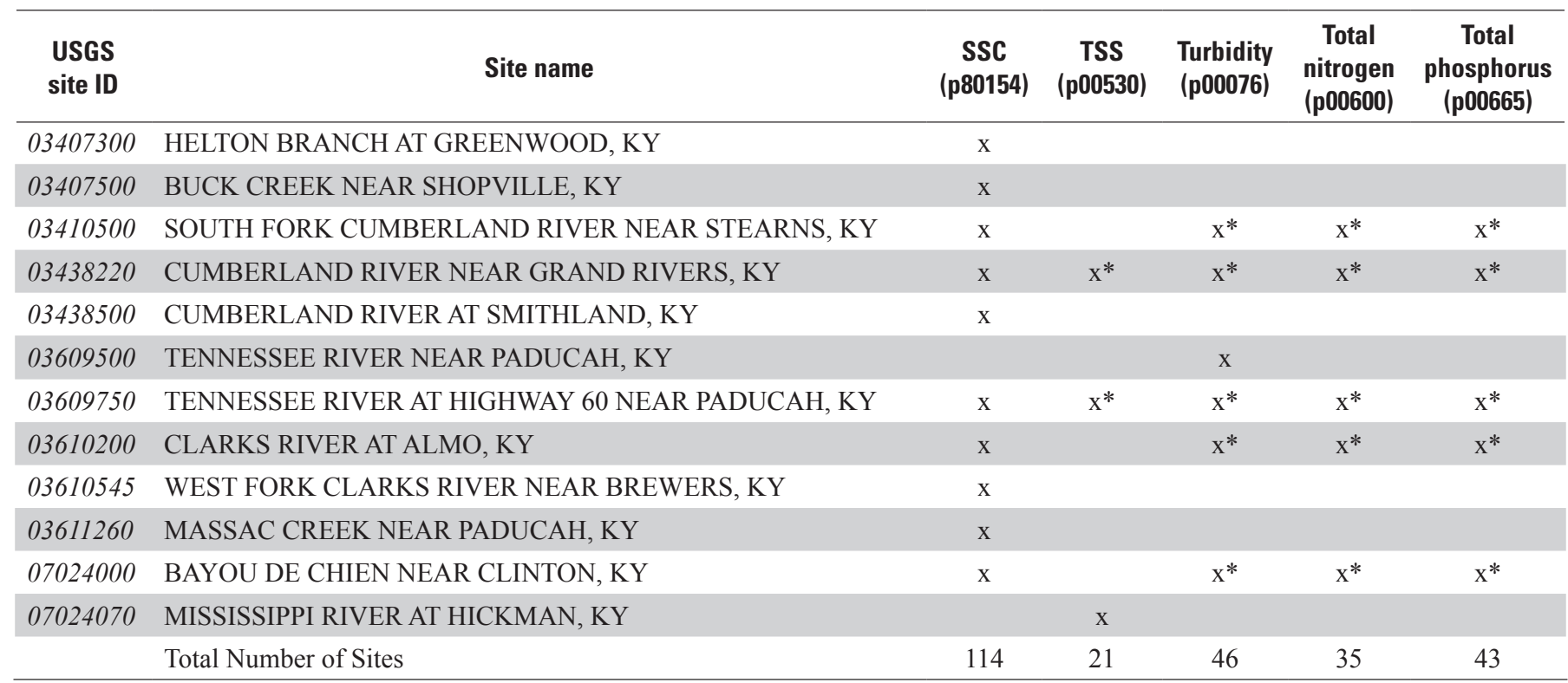




을

产

뭉

용

蛋

$\Xi$

졸

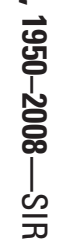

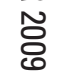

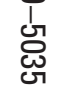

